\title{
Evaluación de ambientes virtuales de aprendizaje. Una gestión para mejorar
}

\section{Evaluation of virtual learning environments. A management to improve}

Rubí Estela Morales-Salas. Institute of Knowledge Management and Learning in virtual environments. Virtual University System - University of Guadalajara (Mexico). rubi.morales@suv.udg.mx

Juan Carlos Infante-Moro. Department of Financial Economics, Accounting and Operations Management. University of Huelva (Spain). juancarlos.infante@decd.uhu.es

Julia Gallardo-Pérez. Department of Financial Economics, Accounting and Operations Management. University of Huelva (Spain). julia.gallardo@decd.uhu.es

\section{RESUMEN.}

Este artículo diseña un instrumento (en formato Lista de cotejo) para evaluar cualquier plataforma como un Ambiente Virtual de Aprendizaje (AVA) y muestra los resultados de la evaluación de un ambiente de aprendizaje a través de este instrumento, en este caso, el ambiente analizado son los espacios con los que cuenta el Ambiente Virtual de Aprendizaje del Departamento de Educación Virtual de la Universidad de Granma (Cuba).

El instrumento se diseña respondiendo a cuatro espacios o indicadores generales: Espacio de Información, Espacio de Mediación/Interacción, Espacio de Diseño Instruccional y Espacio de Exhibición, con el fin de identificar debilidades para tomar acciones hacia la mejora de la plataforma y la interacción virtual entre el asesor y los alumnos, y crear estrategias que ayuden a aminorarlas o eliminarlas para contribuir a la mejora de los cursos diseñados para ambientes virtuales de aprendizaje.

\section{PALABRAS CLAVE.}

Ambientes Virtuales de Aprendizaje (AVA); sistema de aprendizaje; análisis; universidad; TIC-Educación.

\section{ABSTRACT.}

This paper designs an instrument (in Checklist format) to evaluate any platform as a Virtual Learning Environment (VLE) and shows the results of the evaluation of a learning environment through this instrument, in this case, the analyzed environment are the spaces that the Virtual Learning Environment of the Department of Virtual Education of the University of Granma (Cuba) has.

The instrument is designed in response to four spaces or general indicators: Information Space, Mediation/Interaction Space, Instructional Design Space and Exhibition Space, in order to identify weaknesses to take actions towards the improvement of the platform and

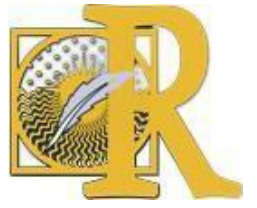


virtual interaction between the advisor and the students, and create strategies that help to reduce or eliminate them to contribute to the improvement of courses designed for virtual learning environments.

\section{KEY WORDS.}

Virtual Learning Environments (VLEs); learning system; analysis; university; ICT-Education.

\section{Introduction.}

In a preliminary way, a virtual learning environment can be conceived as a space where activities are carried out using technologies, such as: Internet, multimedia materials and learning objects, among others, which have significantly changed traditional education (Bournissen, Tumino \& Carrión, 2019; Blanco, Pérez, Arjona \& Cordón, 2018; Yanacón-Atía, Costaguta \& Menini, 2018; Infante-Moro, Infante-Moro, Torres-Díaz \& Martínez-López, 2017; Torres-Díaz, Infante Moro \& Valdiviezo Díaz, 2014).

These environments encourage situations for the student to apply knowledge, experiences and new elements, and form processes of analysis, reflection and understanding, but above all of content appropriation. Without forgetting that the distance aspect is present, that is, there is no physical presence.

Belloch (2012) addresses that an environment is a combination of resources, interactivity, support and structured learning activities, and that in order to develop them we must know the strengths and limitations of the computer support or virtual platform to be used.

The platforms are adaptable to the characteristics and needs of the user as they have different roles, teachers, tutors, administrators and students, thus enabling communication and interaction between student, teacher and tutor.

UNESCO (1998), in its world education report, points out that virtual learning environments constitute a totally new form of Educational Technology and offer a complex series of opportunities and tasks to teaching institutions around the world, defining the Virtual learning environment as an interactive computer program of a pedagogical nature that has an integrated communication capacity, that is, associated with New Technologies.

López Rayón Parra, Escalera Escajeda and Ledesma Saucedo (2002) define the virtual learning environments as "sets of interactive, synchronous and asynchronous environments, where, based on curricular programs, teaching-learning processes are carried out, through systems of learning administration".

And for Monroy, Ladino and Sánchez (2013), learning environments are the gathering of factors within which the set of interactions between individuals affect, in order to achieve learning. These factors are physical, psychological, technological, content, interaction and, very important, efficient communication.

They all mention that the characteristics of learning environments are varied, but can be referred to as follows if a general analysis is made: 
- They facilitate to those who are located in it, the promotion and reinforcement of feelings of security and dignity.

- Promotion and reinforcement of experiences, attitudes and multiple relationships with the environment and the infrastructure necessary for the accumulation of the purposes of an educational proposal.

- They refer to the physical environment.

- They also refer to the interactions produced in the learning environment.

- They are based on a need.

- They consider the general psychological processes and principles of learning.

- They consider the nature of the contents and processes required for their learning.

- They should consider the characteristics of the people to whom they are addressed.

- They are delimited environments.

- They are moving environments.

- They can be face-to-face or virtual

Thus, these learning environments benefited from the incorporation of technologies and the internet, are strengthened in Distance Education, where activities take place, without the physical presence between students and advisors, on a platform (with the use and help from various media with a specific instructional design).

Similarly, the virtual learning environment has involved ways of working where technology and interaction between the participants are implemented, developing lessons in online courses where planning, instructional design, monitoring and evaluation are required.

In that way, the means, the instruments, the materials, a certain methodology and the interaction between the participants, do not guarantee learning and that optimal results are obtained. Avila and Bosco (2001) point out that these only contribute to be carried out in a certain way, but that it also requires a process of construction, assimilation, understanding, responsibility and determination on the part of the student.

Then, students learn certain content, develop skills, creativity and competencies, and interact with the reality of the context where it develops, using reason, making value judgments, proposing strategies or solving problems.

Therefore, in a Virtual Learning Environment (where the student is responsible for their development and progress in the program they are studying), autonomous learning is decisive.

Valle et al. (2007) points out that autonomous learning refers to the degree of student intervention in establishing their objectives, procedures, resources, evaluation and learning moments, from the active role they must have in relation to current training needs (in which the student can and should contribute his previous knowledge and experiences, to try to revitalize the learning and give it significance). 
Martí (2000) states that it is the intellectual process through which the subject implements cognitive and metacognitive, sequential, objective, procedural and formalized strategies to obtain strategic knowledge. This process is governed by principles of action such as: a manifest interest in reasons that motivate deliberate action; recognition of previous learning experiences; the establishment of new relationships between learning - work - everyday life, as well as between theory and practice; the identification of intrinsic motivation; and the development of the personal potential of self-regulation.

For Martínez (2004), autonomous learning is a process where the student self-regulates their learning and becomes aware of their own cognitive and socio-affective processes. This awareness is what is called metacognition. The pedagogical effort in this case is oriented towards the formation of subjects focused on solving specific aspects of their own learning, and not only on solving a specific task, that is, orienting the student to question, review, plan, control and evaluate their own learning action.

Based on all of the above, it can be affirmed that autonomous learning is favored with the interaction between participants, where messages and contributions (when displayed and shared on the platform) allow students to receive new contributions, feedback, doubts, refutations, questions, congratulations, etc., and allow them to reflect, analyze and deepen the contributions, being able to modify or debate and defend the content of their messages (which also reports them experiencing learning).

That is why, Distance Education and, specifically, virtual learning environments, must be taken care of in a profound way, to identify: what is happening inside the virtual environment, how activities are carried out in the platform, if the planned learnings are those that are being developed and, especially, if the spaces that the platform has are desirable for the achievement of these learning and objectives (Pinto Corredor, Agredo Delgado \& Collazos, 2018; Forneiro, 2008; González, 2000).

Therefore, it is essential to investigate the spaces that have the Virtual Learning Environment of the Department of Virtual Education of the University of Granma in Cuba, specifically on the platform where educational programs are developed, since there is no physical presence of a teacher, advisor, facilitator or teacher to guide, transmit or guide the contents, and students are not subject to fixed schedules, facilities and transfers; that is, that knowledge is approached in a flexible manner, which also adjusts to the needs and availability of time of each student regardless of age, social status or personal status.

Although in these environments, the student and autonomous learning are the center of everything, the teacher continues to be a determining figure in the student's learning, because in addition to being an expert in his area and in the subject he advises, he has theoretical knowledge and technical and pedagogical skills to promote and motivate learning in students (Morales Salas, Infante-Moro \& Gallardo-Pérez, 2019; Martínez, 2017).

Thus, it also acts as a mediator of the educational process in the field of planning, work dynamics, instructional design and learning strategies, in order to generate knowledge. What causes that the adviser must handle the platforms in an organized, clear and concrete way, to achieve this mediation with optimum quality. But what should the platforms contain to allow compliance with these quality standards? 
For Boneu (2007) there are four basic and essential characteristics that any platform (such as a Virtual Learning Environment) should have:

- Interactivity: make the person using the platform aware that he is the protagonist of his training.

- Flexibility: set of functionalities that allow the e-learning system to have an easy adaptation in the organization where you want to implement, in relation to the institutional structure, the study plans of the institution and, finally, to the contents and styles Pedagogical organization.

- Scalability: the ability of the e-learning platform to work equally with a small or large number of users.

- Standardization: Possibility to import and export courses in standard formats such as SCORM (Sharable Content Object Reference Model), which are a set of standards and specifications that allow to create structured pedagogical objects.

And one of the main characteristics of the Virtual Learning Environments, from the perspective of communicative processes, is that they must have very limited spaces, which Chan refers to as follows:

"- The information space is where the various types of materials to be processed are located. In this space you can present the information organized or to be inquired by the students. Information can be provided by various means: exhibitions, documents, databases, images, graphics, $\ldots$

- The interaction space is one in which situations are arranged so that the subjects of the information exchange information of all kinds: opinions, products of their work, doubts, projects, creative expressions, ...

- In the production space there are tools and devices for information processing, exercise and problem solving.

- And the exhibition space is characterized by being a space for the circulation of learning products, for the socialization of its results. In this space, students express the achievements of their effort and, in turn, expose what they find in the products of others" (2004, p.10).

\section{Methodology.}

Based on the previous information of Chan (2004), the researchers proceeded to develop an instrument that could evaluate virtual learning environments, which consists of 4 spaces:

1. Information Space: it presents sufficient information about the planning and development of the course, the organization and scheduling of all learning activities that the student will have to execute.

2. Mediation/Interaction Space: it presents the functions of orientation, motivation, organization and management of the teaching and learning process, from the figure of the advisor and the interaction with the student. It also promotes and encourages the analysis, synthesis and appropriation of information to obtain meaningful learning. 
4. Instructional Design Space: it presents the methodology used in the course: objectives, competencies that are intended to be achieved, clear and objective drafting of instructions that contain the activities that meet the congruence of the objective and competence to achieve. The digital teaching resources (digital books, notes, notebooks, instructions, audiovisuals, blog, web pages, multimedia, simulators, wikis, learning objects, among others (Infante-Moro, Infante-Moro \& Gallardo-Pérez, 2019)) will also be presented in this space.

5. Exhibition Space: it presents access and flexibility to the interaction between students and advisors through the design of the educational platform, its design and automation. All this to ensure that students reach high levels of metacognition.

The design of this instrument was unanimously validated by experts, and subsequently it was applied (the results are shown below).

Thus, for the present study, the following research questions were formulated:

a) Does the platform as a virtual learning environment (VLE) of the Department of Virtual Education of the University of Granma have defined spaces?

b) Does the platform as VLE of the Department of Virtual Education of the University of Granma in its Higher Education courses present the organized information?

c) Does the mediation and interaction that occurs on the platform as VLE of the Department of Virtual Education of the University of Granma in its Higher Education courses, contain sufficient elements for the exchange of information of all kinds?

d) Does the instructional design of the courses hosted in an VLE of the Department of Virtual Education of the University of Granma in its Higher Education courses present sufficient elements to process all types of information?

e) Can the advisor and the student evaluate the interaction spaces of the virtual learning environment of the Department of Virtual Education of the University of Granma?

And once the questioning was obtained, it was sought to fulfill the general objective of this research: to evaluate a virtual learning environment through an instrument that identifies weaknesses to take actions towards the improvement of the platform and the virtual interaction between the Advisor and students.

\subsection{Context.}

The present study was carried out in the Department of Virtual Education of the University of Granma (Cuba) during the period from August to December 2017, taking a sample of 15 advisors who teach different subjects in the Higher Education Programs with a blended (face-to-face) mode and online or virtual). The online part is the one that was evaluated.

The criteria for selecting the participating advisors were those of being an advisor to any subject that is taught semi-in-person of any of the degree programs offered at the University of Granma (Cuba), having a minimum teaching experience of three years and knowing concepts about virtual environments. 


\subsection{Process.}

It was positioned as a non-experimental, descriptive-transversal research, with a mixed approach (since it only measured or collected information independently or jointly on the concepts or reference categories).

According to Danhhke: "descriptive studies seek to specify the properties, characteristics and important profiles of people, groups, communities or any other phenomenon that are incorporated into an analysis" (Hernández, Fernández \& Baptista, 2014: 102).

Specifically, according to Hernández, Fernández and Baptista (2014), this study was crosssectional because data were collected in a single moment, in a single time, whose purpose was to describe variables and analyze their incidence and interrelationship at a given time, it is like Take a picture of something that happens.

Likewise, Hernández, Fernández and Baptista (2014) point out that the description of phenomena, situations and events in a natural situation, allows the generalization of results so as not to be subject to a rigorous control, typical of laboratory research. Obviously, methodological, quantitative and qualitative strategies offer divergent views.

Based on the analysis of the participating researchers, an instrument was designed under the format "Checklist to evaluate Virtual Learning Environments" (Table 1), using as spaces the spaces from the perspective of the communicative processes, which Chan (2004) refers, that is: informative, interactive, production and exhibition. With some adaptations to it taking into account their agreements and which were defined above.

The general indicators that were included for the design of the Checklist to evaluate Virtual Learning Environments were: a) Information Space, b) Mediation/Interaction Space c) Instructional Design Space and d) Exhibition Space. And, in addition, criteria were used according to the functions and activities performed by the advisor and the virtual student, which arise from the analysis and interaction of the advisors achieved in discussion meetings and academic activities through collaborative work in the workshop course " Didactics focused on student learning in virtual environments "(developed in August 2017 at the aforementioned university).

Below is the instrument in its final version (Table 1): 
Indicators

\begin{tabular}{|c|c|}
\hline Indicators \\
\hline Information space \\
\hline Mediation/Interaction \\
Space
\end{tabular}

Space

\section{Evaluation criteria}

1 Information on the planning of the course, as well as the development of the course, is presented on the platform.

2 They display the course information in an organized and scheduled manner.

3 The platform has graphics and images that make the information more attractive.

4 The graphics and images are sufficient, relevant and clear.

5 Present videos that complement the information.

6 There is congruence in the videos for the purpose of learning and they have a high quality in both audio and images.

1 The advisor fulfills the functions of orientation, motivation and organization of the learning process in a timely manner.

2 The advisor plays the role of analyst and guide.

3 Instructs, advises and evaluates the adviser to his students in a timely manner.

4 The advisor performs the role of instrumenter and intercom, planning and facilitating the use of available teaching resources.

5 The advisor manages the learning groups.

6 Select and use technological resources according to the established objectives (email, forums, chat, netmeeting, wikis) as support for communication and interaction with students (synchronous and asynchronous).

7 The work of a planner and manager is carried out in the development of the course by the advisor.

8 The advisor organizes the group work and facilitates coordination among the members.

9 The consultant facilitates intellectual / conceptual work techniques for collaborative network study.

10 The advisor motivates and ensures that students work at an appropriate pace.

11 The advisor promotes and encourages the analysis, synthesis and appropriation of information to obtain meaningful learning.

12 Information is provided to the student about the progress of study by the advisor.

13 The advisor organizes the interaction by clearly defining the roles of the student and advisor.

14 Promotes work in the group, between students and advisor, favoring the development of arguments and strengthening collaborative and cooperative work.

15 The advisor encourages, stimulates, integrates and conducts student participation.

16 The advisor energizes the training and group work.

17 The adviser provides timely feedback, adding value to the activity carried out by the student.

18 Upon feedback, the advisor respectfully suggests proposals to improve the activity delivered by the student.

19 Questions or messages are answered by the advisor within 24 hours to the students.

20 The advisor suggests extra didactic material (apart from the one that comes in resources).

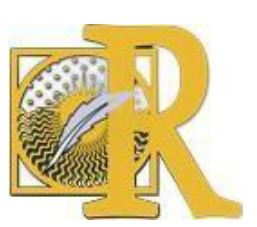




\begin{tabular}{|c|c|c|c|}
\hline Indicators & Evaluation criteria & YES & $\mathrm{NO}$ \\
\hline \multirow{5}{*}{ Mediation/Interaction Space } & 21 The advisor uses videoconferencing to explain doubts. & & \\
\hline & $\begin{array}{l}22 \text { The advisor uses teaching resources with different formats (video, graphics, } \\
\text { maps, tutorials, among others). }\end{array}$ & & \\
\hline & 23 The advisor promotes metacognition. & & \\
\hline & 24 The advisor recovers the previous knowledge of the students. & & \\
\hline & $\begin{array}{l}25 \text { The advisor determines the evaluation criteria, qualitative and qualitative and informs } \\
\text { students in a timely and clear manner. }\end{array}$ & & \\
\hline \multirow{28}{*}{ Instructional Design Space } & 1 The methodology used in the course allows students to reach high cognitive levels. & & \\
\hline & 2 Complete the course with learning the skills necessary to be part of the knowledge. & & \\
\hline & 3 The learning objectives are well defined. & & \\
\hline & $\begin{array}{l}4 \text { The instructions were written in a clear and objective manner that does not allow } \\
\text { misinterpretation. }\end{array}$ & & \\
\hline & 5 They present information that implies different forms of relationship with the environment. & & \\
\hline & $\begin{array}{l}6 \text { The instructions for learning activities are in accordance with the objective to be } \\
\text { achieved. }\end{array}$ & & \\
\hline & 7 The instructions present a logical order. & & \\
\hline & 8 Learning activities are sufficient for the achievement of skills. & & \\
\hline & 9 The teaching resources are congruent with the objective that is intended to be achieved. & & \\
\hline & 10 Sufficient resources are presented for carrying out the activities. & & \\
\hline & 11 The teaching resources have relevant quality and provide value for learning. & & \\
\hline & 12 Designed activities promote metacognition. & & \\
\hline & 13 Designed activities allow students to recover their previous knowledge. & & \\
\hline & 14 Evaluation criteria are presented for each of the activities. & & \\
\hline & 1 The platform is friendly in its navigation and allows quick access to information. & & \\
\hline & $\begin{array}{l}2 \text { There are adequate spaces on the platform that allow interaction between students and } \\
\text { advisors. }\end{array}$ & & \\
\hline & $\begin{array}{l}3 \text { Presents the flexibility platform to modify the content modules of a course that is already } \\
\text { online. }\end{array}$ & & \\
\hline & 4 Information organization is presented in chronological order. & & \\
\hline & 5 Platform elements are displayed quickly. & & \\
\hline & 6 There are tools and spaces to provide feedback. & & \\
\hline & 7 The platform allows subsequent delivery of tasks. & & \\
\hline & $\begin{array}{l}8 \text { The platform allows you to attach several files, as well as edit them when you want to } \\
\text { modify. }\end{array}$ & & \\
\hline & $\begin{array}{l}9 \text { The design of the platform is friendly and allows the incorporation of blogs and wikis for } \\
\text { collaborative work. }\end{array}$ & & \\
\hline & 10 The platform is updated automatically. & & \\
\hline & 11 The platform has forum spaces to resolve doubts immediately. & & \\
\hline & 12 The platform has chat. & & \\
\hline & 13 The platform allows the design of relevant evaluation instruments. & & \\
\hline & 14 It has adequate spaces that allow students to check their own progress. & & \\
\hline
\end{tabular}

Table 1. Checklist to evaluate Virtual Learning Environments. Source: Self-made based on Chan (2004) and Morales and Pereida (2017). 


\section{Results.}

The results are shown below by graphing, obtained from the application of the instrument. Figure 1 shows that questions 3, 4, 5 and 6 are items that should be taken into account to improve the virtual platform, where $33 \%$ of teachers say that the images and graphics that appear on the platform are not relevant neither clear nor provide attractive information.

With respect to questions 5 and $6,60 \%$ say that the videos presented on the platform do not complement the information and, therefore, are not congruent. In addition to showing poor quality in the image and audio.

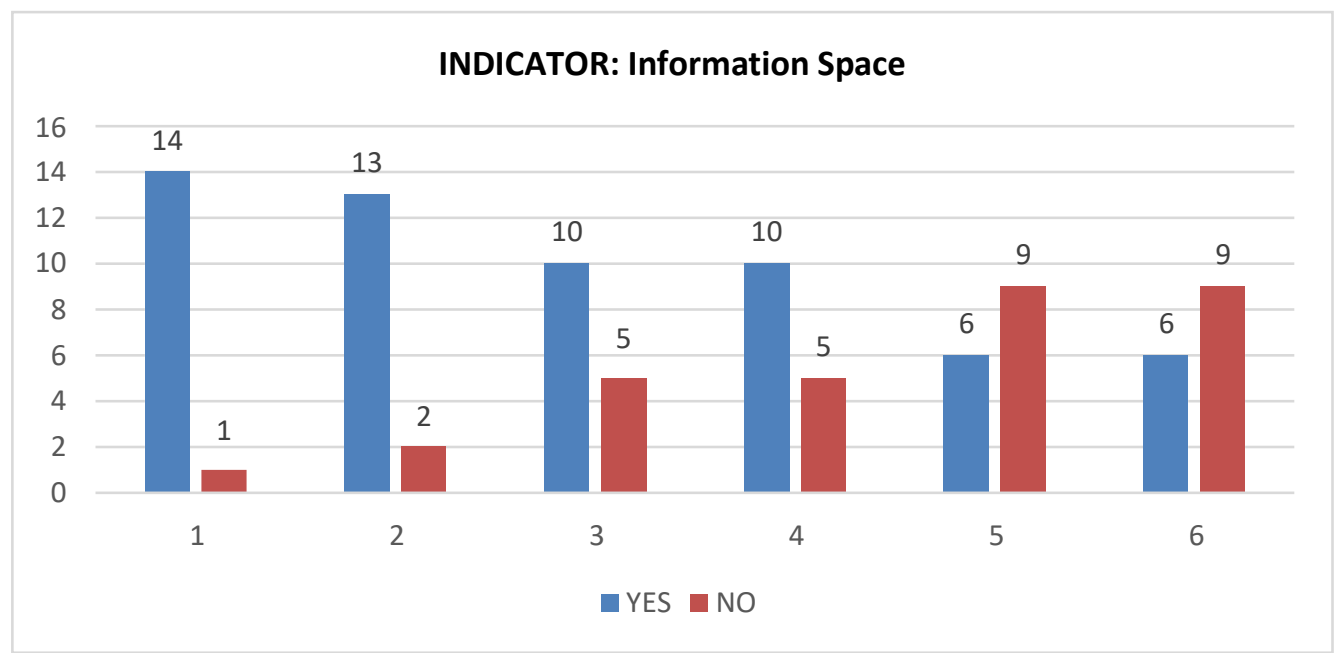

Figure 1. Information Space. Source: Self-made.

In general, there were 31 negative responses out of a total of 90 (equivalent to $34 \%$ of the responses), that is, a third of the teachers surveyed are not satisfied with the way in which the Information Space is presented on their platform virtual (Figure 2).

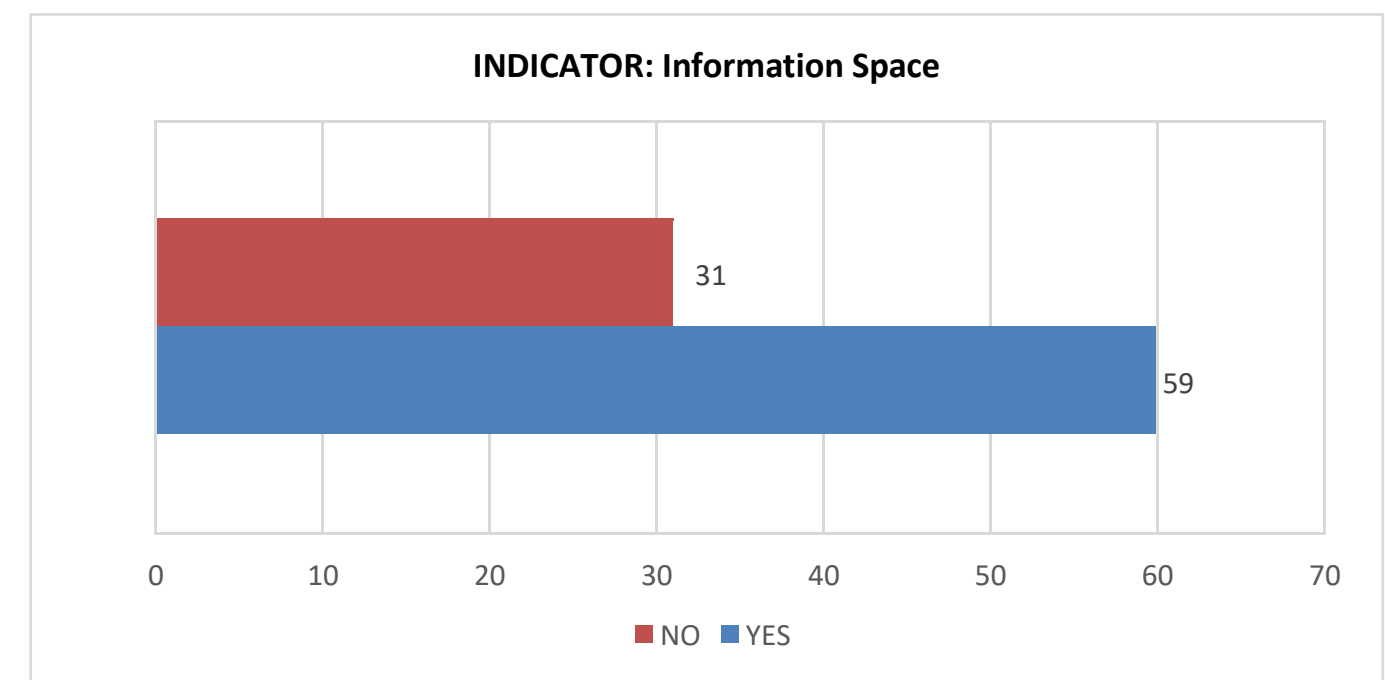

Figure 2. General result: Information Space. Source: Self-made. 
Figure 3 shows that the questions to be considered in a more timely manner are 5, 19, 21 and $22.33 \%$ of teachers say that the teacher or advisor does not manage the learning groups, which does not follow up.

In question 19, $47 \%$ say that students' doubts are not answered before 24 hours.

In question $21,80 \%$ of the advisors express not being able to use videoconferencing to explain questions that students present.

And in question $22,40 \%$ of teachers say they don't use videos, tutorials, concept or mental maps and graphics, on their virtual platforms.

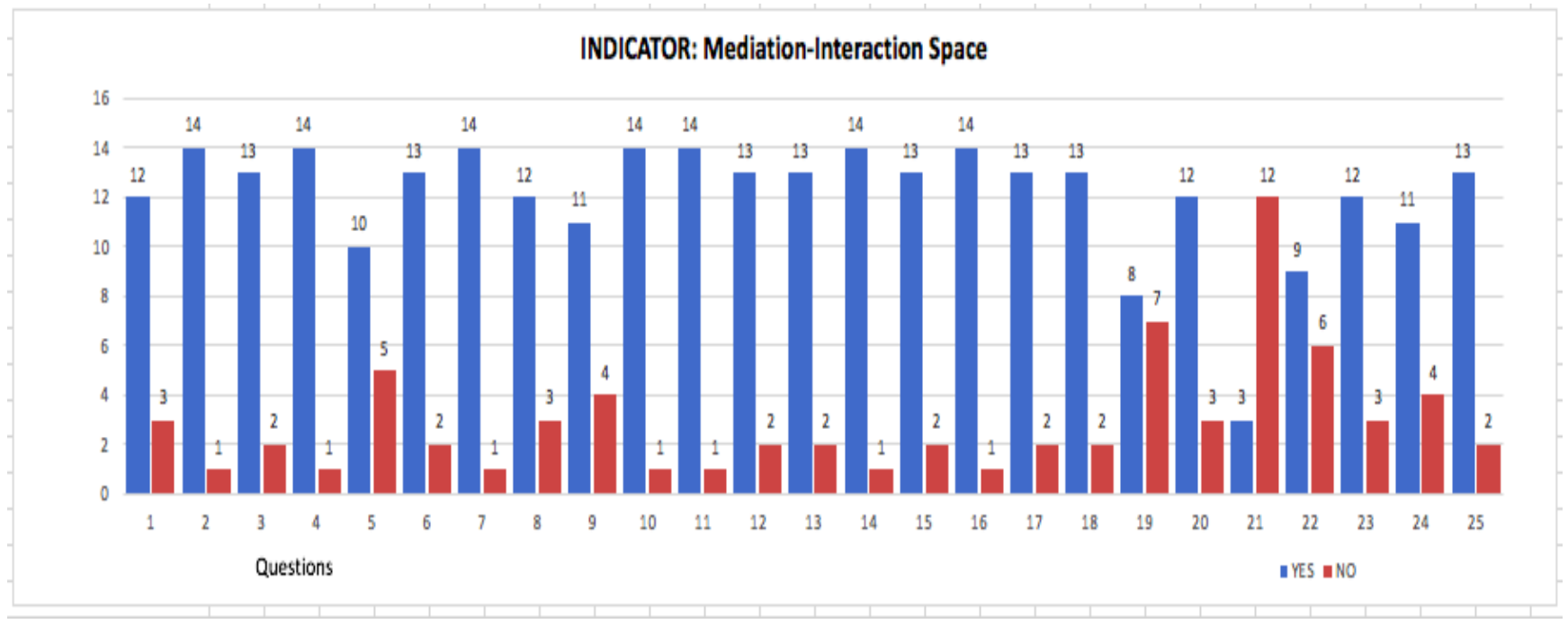

Figure 3. Mediation-Interaction Space. Source: Self-made.

Overall, there were 73 negative responses out of a total of 375 , which means that $19 \%$ of the teachers surveyed are not satisfied with the way in which the Mediation-Interaction Space is presented in their virtual platform (Figure 4).

\section{INDICATOR: Mediation-Interaction Space}

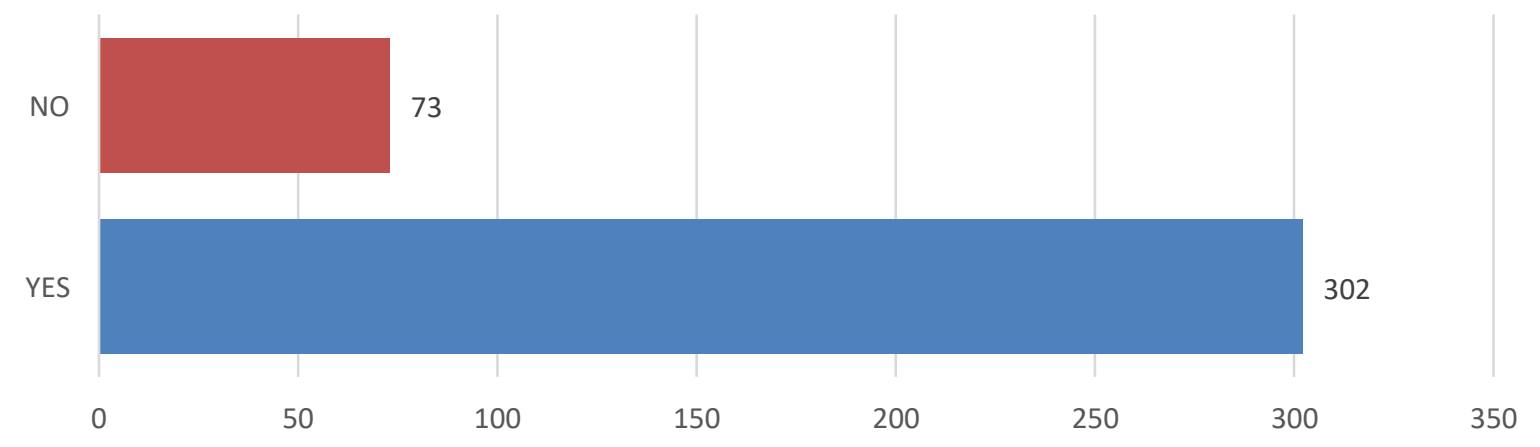

Figure 4. General result: Mediation-Interaction Space. Source: Self-made.

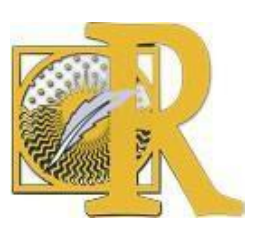


Figure 5 shows that questions 10 and 12 are the ones with the highest score. In question 10, $27 \%$ of the professors say that in their virtual platform not enough resources are presented for students to carry out their activities. And in question $12,20 \%$ say that the activities provided to students do not present an effective design that promotes the goal of cognition.

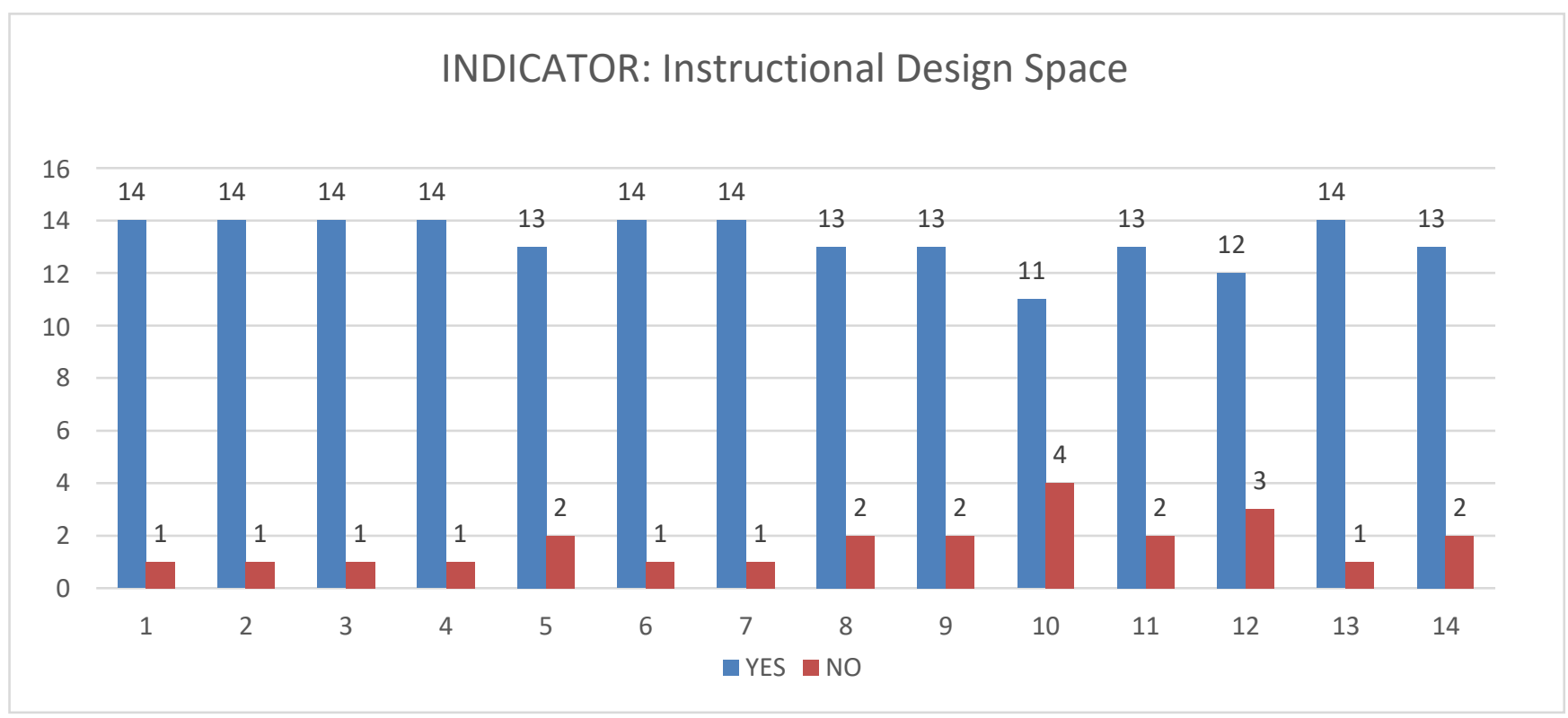

Figure 5. Instructional Design Space. Source: Self-made.

In general, there were 24 negative responses out of a total of 210 , which is equivalent to the fact that $11 \%$ of the professors surveyed are not satisfied with the way in which the Instructional Design Space is presented in their virtual platform (Figure 6).

\section{INDICATOR: Instructional Design Space}

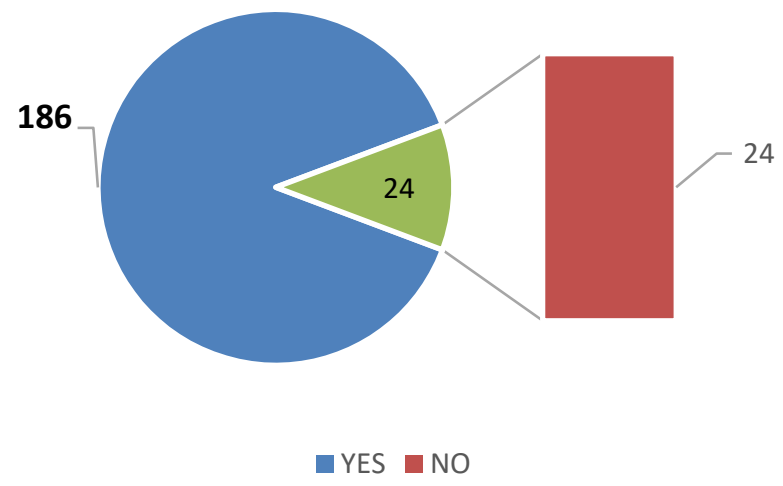

Figure 6. Overall result: Instructional Design Space. Source: Self-made. 
And in the Exhibition space, it is considered that questions 5, 9 and 10 are in which special attention should be paid (Figure 7). In question 5, 33\% of teachers say that the elements that the platform contains are not displayed quickly, but are slow.

In question 9, 40\% say that the design of the platform is not friendly and this favors that wikis or blogs that allow collaborative work between students and advisors cannot be incorporated.

And in question $10,53 \%$ of the teachers surveyed point out that the platform is not updated automatically.

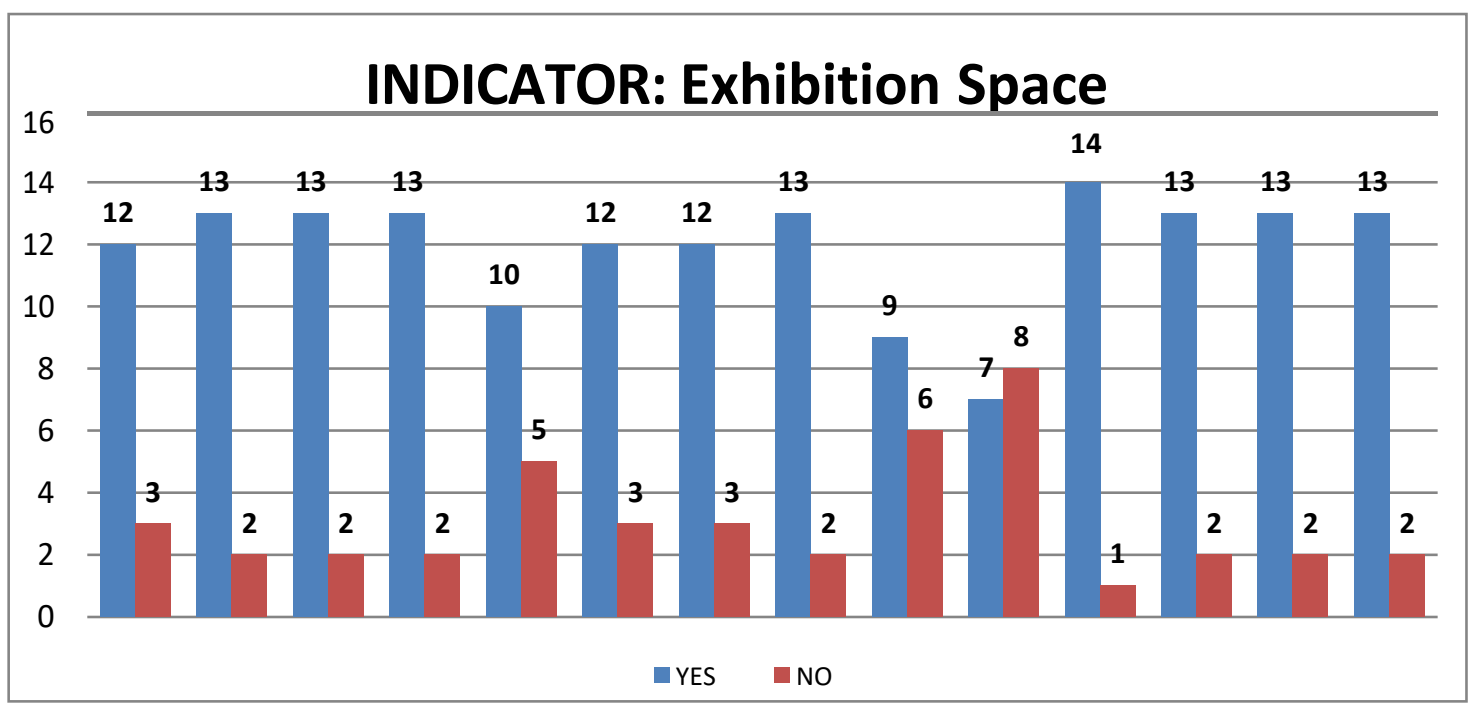

Figure 7. Exhibition Space. Source: Self-made.

Overall, there were 43 negative responses out of a total of 210 , which is equivalent to the fact that $20 \%$ of the teachers surveyed are not satisfied with the way in which the Exhibition Space is presented on their virtual platform (Figure 8).

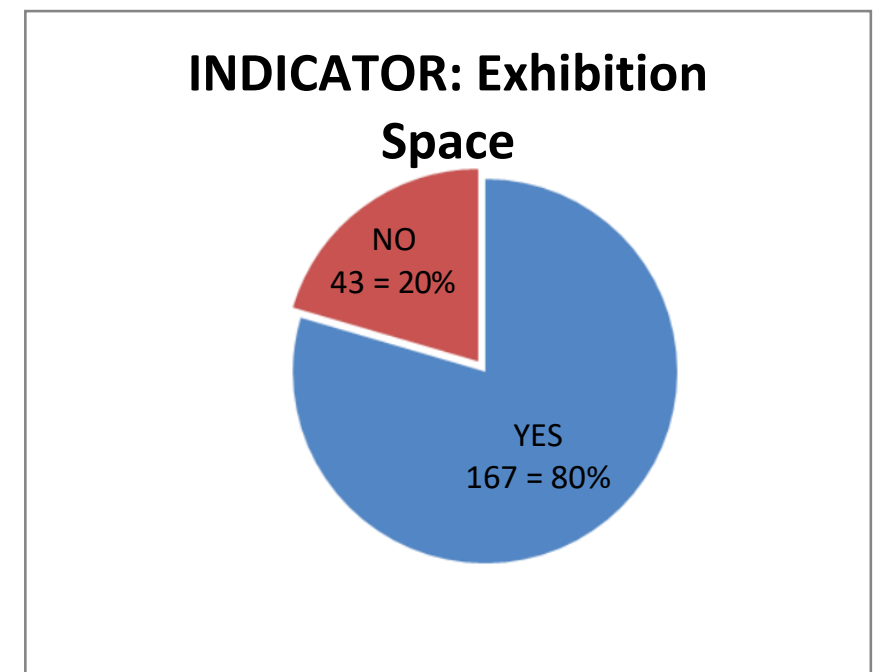

Figure 8. Overall result: Exhibition Space. Source: Self-made.

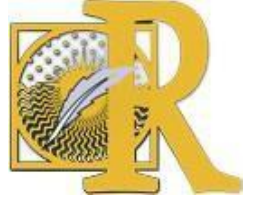




\section{Conclusions.}

In this article, an instrument was designed under the "Checklist for assessing Virtual Learning Environments" (Table 1), whose indicators were: a) Information Space, b) Mediation / Interaction Space c) Instructional Design Space and d ) Exhibition Space, and proceeded to its application.

The design was designed so that both advisors and students could answer it, taking care of the sense of language and its writing. In this first stage it was only applied to teachers.

Its analysis is very useful to improve the spaces of a VLE, since the diversity of criteria that this instrument presents includes in a thorough way the perception and experience of the participating advisors of the platform of the Department of Virtual Education of the University of Granma (Cuba ), who teach different subjects in the Higher Education Programs with a blended modality.

There are many aspects that would have to be analyzed to evaluate a VLE, but, nevertheless, keeping the platforms active is a guarantee that the student acquires the competences efficiently and with optimum quality.

In this case study, with the results obtained, those involved in these virtual learning spaces must take into account the following aspects (translated into weaknesses) to take actions towards the improvement of the platform and the virtual interaction between the advisor and the students.

\section{a) Difficulties arising from the Information Space:}

Images and graphics are not clear and therefore do not provide attractive information.

The videos have poor quality in both image and audio.

Excessive presence of linear text.

Poor creativity and semantic neglect in visual texts and, especially, in photographs.

b) Difficulties arising from the Mediation-Interaction Space:

Groups of students who have activities on the platform are not managed, that is, they are not monitored or given feedback.

No doubts of the students are answered before 24 hours.

Videoconferencing cannot be used to explain questions that students have.

Videos, tutorials, concept or mental maps and graphics are not used on their virtual platforms.

c) Difficulties arising from the Instructional Design Space:

Not enough resources are presented for students to carry out their activities.

The activities provided to students do not present an effective design that promotes the goal of cognition.

Instructional design lacks teaching and learning strategies that result in meaningful activities for the student.

The activities do not favor the acquisition of skills.

Obsession for the generation of literary content.

Tendency to use methodologies of a behavioral nature. 


\section{d) Difficulties arising from the Exhibition Space:}

The elements contained in the platform are not displayed quickly, but are slow.

The design of the platform is not friendly and this favors that wikis or blogs that allow collaborative work between students and consultants cannot be incorporated.

The platform is not updated automatically.

Slow information transmission, especially observable when receiving compressed

multimedia documents or in real time.

Unexpected interruption of communication.

Effect "delay" in audiovisual communication in real time.

Frequent failures in the information servers.

Interruptions in the electricity supply.

These are some of the most significant weaknesses that yielded the results of the evaluation of the virtual learning environment through the instrument applied. The creation of strategies to reduce and, in other cases, eliminate these weaknesses, will be an essential task for the advisors participating in this evaluation; because the imminent global technological development demands greater effectiveness in the teaching-learning processes that are offered through virtuality.

As Torres and Ortega (2003) says, progressive demotivation and the occasional abandonment of the learning process occurs in those cases in which methodological and organizational designs do not favor the establishment of interpersonal relationships (coexistence and online) of students and teachers and of students with each other.

\section{References}

- Avila, P., \& Bosco, M. D. (2001). Ambientes virtuales de aprendizaje. Recuperado de: http://investigacion.ilce.edu.mx/panel control/doc/c37ambientes.pdf

- Belloch, C. (2012) Entornos virtuales de aprendizaje. Recuperado de: http://www.uv.es/bellochc/pedagogia/EVA3

- Blanco, I. J., Pérez, R., Arjona, E., \& Cordón, O. (2018). Aspectos organizativos y estructurales de una iniciativa MOOC institucional: el caso de la UGR. International Journal of Information Systems and Software Engineering for Big Companies (IJISEBC), 5(1), 101-110.

- Boneu, J. M. (2007). Plataformas abiertas de e-learning para el soporte de contenidos educativos abiertos. RUSC. Universities and Knowledge Society Journal, 4(1), 36-47.

- Bournissen, J. M., Tumino, M. C., \& Carrión, F. (2019). MOOC: evaluación de la calidad y medición de la motivación percibida. IJERI: International Journal of Educational Research and Innovation, 11, 18-32.

- Chan, M. E. (2004). Tendencias en el diseño educativo para entornos de aprendizaje digitales. Revista Digital Universitaria, 5(10), 1-26.

- González, M. A. (2000). Evaluación de ambientes de aprendizaje. In V Congreso Iberoamericano Informática Educativa. Santiago de Chile. Recuperado de: http://www.niee.ufrgs.br/eventos/RIBIE/2000/papers/067.htm 
- Hernández, R., Fernández, C., \& Baptista, P. (2014). Metodología de la Investigación. Ciudad de México, México: McGraw-Hill.

- Forneiro, M. L. I. (2008). Observación y evaluación del ambiente de aprendizaje en educación infantil: dimensiones y variables a considerar. Revista lberoamericana de educación, 47(3), 49-70. Recuperado de: http://www.rieoei.org/rie47a03.htm

- Infante-Moro, A., Infante-Moro, J. C., \& Gallardo-Pérez, J. (2019). The Importance of ICTs for Students as a Competence for their Future Professional Performance: the Case of the Faculty of Business Studies and Tourism of the University of Huelva. Journal of New Approaches in Educational Research, 8(2), 201-213. doi: 10.7821/naer.2019.7.434

- Infante-Moro, A., Infante-Moro, J. C., Torres-Díaz, J. C., \& Martínez-López, F. J. (2017). Los MOOC como sistema de aprendizaje en la Universidad de Huelva (UHU). IJERI: International Journal of Educational Research and Innovation, 7, 13-24.

- López Rayón Parra, A. E., Escalera Escajeda, S., \& Ledesma Saucedo, S. (2002). Ambientes Virtuales de Aprendizaje. Presimposio Virtual SOMECE. Recuperado de: https://studylib.es/doc/455916/ambientes-virtuales-de-aprendizaje

- Martí, E. (2000). Metacognición y estrategias de aprendizaje. In Pozo, J.I., \& Monereo, C. El aprendizaje estratégico. Madrid: Aula siglo XXI, Santillana.

- Martínez, D. D. (2017). Profesorado en formación y ambientes educativos virtuales. Campus Virtuales, 6(2), 69-78.

- Martínez, J. R. (2004). Concepción del aprendizaje, meta cognición y cambio conceptual en estudiantes universitarios de Psicología. [Tesis doctoral]. Universidad de Barcelona

- Monroy, E., Ladino R., \& Sánchez S. (2013). Diseño de un ambiente de aprendizaje como herramienta para el área de tecnología e informática. In Congreso Investigación y Pedagogía. Tunja. Recuperado de: http://tics.uptc.edu.co/eventos/index.php/cong inv pedagogia/con inv pedag/paper/viewFile/11/11

- Morales, R. E., \& Pereida, M. A. (2017). Inclusió n de estilos de aprendizaje como estrategia didá ctica aplicada en un AVA. Campus Virtuales, 6(1), 67-75.

- Morales Salas, R. E., Infante-Moro, J. C., \& Gallardo-Pérez, J. (2019). La mediación e interacción en un AVA para la gestión eficaz en el aprendizaje virtual. Campus Virtuales, 8(1), 49-61.

- Pinto Corredor, J. D., Agredo Delgado, V., \& Collazos, C. A. (2018). Construyendo una guía para la evaluación de la usabilidad en EVAs. Campus Virtuales, 7(2), 93-104.

- Torres-Díaz, J. C., Infante Moro, A., \& Valdiviezo Díaz, P. (2014). Los MOOC y la masificación personalizada. Profesorado: Revista de curriculum y formación del profesorado, 18(1), 63-72. 
- Torres, S., \& Ortega, J. (2003). Indicadores de calidad en las plataformas de formación virtual: una aproximación sistemática. Recuperado de: http://www.ugr.es/ sevimeco/revistaeticanet/Numero1/Articulos/Calidade.pdf

- UNESCO (1998). Conferencia mundial sobre la educación superior. Recuperado de: http://ciie.itesm.mx/es/tipos-de-contribuciones/

- Valle, A., Núñez, J. C., Cabanach, R. G., Rodríguez, S., González-Pienda, J. A., \& Rosario, P. (2007). Metas académicas y estrategias motivacionales de autoprotección. Electronic Journal of Research in Educational Psychology, 5(3), 617-632.

- Yanacón-Atía, D.; Costaguta, R.; Menini, M. de los A. (2018). Indicadores colaborativos individuales y grupales para Moodle. Campus Virtuales, 7(1), 125-139. 